\title{
Workforce Nationalization in the Gulf Cooperation Council States
}

Kasim Randeree

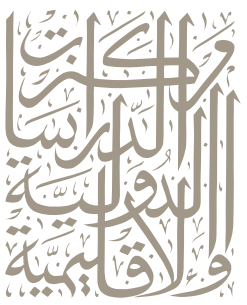

CIRS

CENTER FOR

INTERNATIONAL AND REGIONAL STUDIES

GEORGETOWN UnIVERSITY SCHOOL OF FOREIGN SERVICE IN QATAR

(C) 2012 


\section{Workforce Nationalization in the Gulf Cooperation Council States}

Kasim Randeree

(C) 2012 Center for International and Regional Studies Georgetown University School of Foreign Service in Qatar

Occasional Paper No. 9

ISSN 2072-5957 


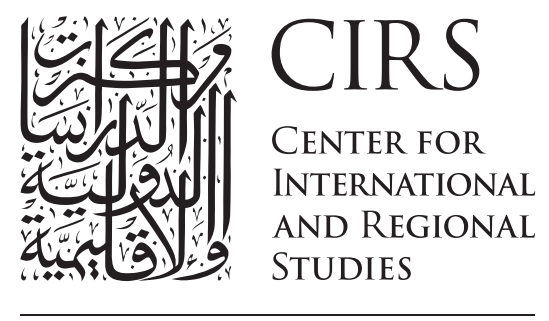

GEORGETOWN UNIVERSITY

SCHOOL OF FOREIGN SERVICE IN QATAR

Established in 2005, the Center for International and Regional Studies at the Georgetown University School of Foreign Service in Qatar is a premier research institute devoted to the academic study of regional and international issues through dialogue and exchange of ideas, research and scholarship, and engagement with national and international scholars, opinion makers, practitioners, and activists.

Guided by the principles of academic excellence, forward vision, and community engagement, the Center's mission revolves around five principal goals:

- To provide a forum for scholarship and research on international and regional affairs

- To encourage in-depth examination and exchange of ideas

- To foster thoughtful dialogue among students, scholars, and practitioners of international affairs

- To facilitate the free flow of ideas and knowledge through publishing the products of its research, sponsoring conferences and seminars, and holding workshops

designed to explore the complexities of the twenty-first century

- To engage in outreach activities with a wide range of local, regional, and international partners.

This publication series is made possible by the generous support of Qatar Foundation for Education, Science and Community Development. 


\title{
Workforce Nationalization in the Gulf Cooperation Council States
}

\author{
Kasim Randeree
}

Kasim Randeree, Senior Researcher at Saïd Business School and Kellogg College, University of Oxford, specializes in the study of the Muslim diaspora. He has contributed to the government and private sector across the Organisation of Islamic Cooperation (OIC) member countries and has published extensively on the Arab Gulf states in particular. His research has included studies in leadership; human resource management; Islamic branding and marketing; the global Halal trade; corporate Waqf (Islamic endowments); higher education in the GCC; and the management of mega projects and mega events. He has worked as an academic for the universities of Oxford, Manchester, Hull, Coventry, and Lincoln in the United Kingdom, and the United Arab Emirates University, The British University in Dubai, and the American University in Dubai in the UAE.

\section{Acknowledgements}

The author is deeply honored to have been invited by the Center for International and Regional Studies (CIRS), Georgetown University School of Foreign Service in Qatar, to participate in the CIRS "Migrant Labor in the Gulf" research initiative. The author would further like to thank The BT Centre for Major Programme Management, Saïd Business School, University of Oxford; The Oxford Centre for Corporate Reputation, University of Oxford; Santander Universities; and The British University in Dubai for their support of this work. The author also extends his thanks to Ms. Anjli Narwani from the University of Sharjah for her assistance with data collection during the early stages of research. 


\begin{abstract}
In recent decades, the Gulf Cooperation Council (GCC) states have become reliant on migrant workers to the extent that foreign inhabitants constitute nearly one-third of the total GCC population. Qatar and the UAE are at the extremity of the situation, where indigenous citizens constitute only one-quarter and one-fifth of their national populations, respectively. Consequently, workforce nationalization - the concept of reducing expatriate employment by bringing more citizens into the workplace-has become the human resource management strategy of all GCC countries.

In this first attempt to review all six GCC nations, this paper takes an exploratory-cum-constructivist approach and argues that closer cooperation and unified policy structures on nationalization are needed across all GCC countries. Education, training, the transfer of knowledge from expatriate to citizen, better approaches to encouraging citizens into the private sector, and the greater inclusion of women are all significant issues that need to be tackled in order to fulfill the desired goal of nationalizing the labor force across all GCC states. A clear and unified policy in terms of structural reform across GCC countries needs to be collectively defined, although methods of implementation would need to be more tailored and distinctive from one country to another.
\end{abstract}

\title{
Introduction
}

Limited research has been conducted on the GulfCooperation Council (GCC) states' efforts at preparing nationals — or local citizens - for entry into the skilled workforce. Instead, much of the current literature on the topic has focused on the causes and means of labor nationalization schemes, and only a limited body of knowledge exists to guide and shape the success of such schemes. Labor nationalization efforts are the stated goals and articulated policies of all the GCC states. ${ }^{1}$ Essentially, these are schemes designed to reduce the extensive reliance on foreign labor by encouraging, often compelling, private sector industries to hire nationals instead of foreign expatriates. Nonetheless, across the region, most of the policies designed to tackle the issue of nationalizing the labor force have faced difficulties in implementation, with little research available to inform and guide policymakers. Despite its centrality as a policy objective across the GCC, workforce nationalization remains understudied and insufficiently researched.

${ }^{1}$ Kasim Randeree, "Strategy, Policy, and Practice in the Nationalization of Human Capital: 'Project Emiratization," Research and Practice in Human Resource Management 17, no. 1 (2009): 71-91. 
This first attempt to review all six GCC nationalization schemes examines the catalysts of success as well as the difficulties involved in nationalizing GCC states' workforces. In this study, nationalization as a strategic process is evaluated in order to understand the extent to which citizens could play a more central role in the development of their national economies. To date, the most extensive studies on labor nationalization have concentrated on the United Arab Emirates (UAE), and, therefore, much of the empirical analysis in this paper draws on the UAE data. Given the similarities with other GCC labor markets and patterns of development, important parallels and conclusions about other GCC cases can be analyzed according to the UAE model.

Currently, the six nations of the GCC all share an over-reliance on migrant labor; high rates of citizen unemployment; education systems that are still undergoing fundamental development; an inadequate gender balance in the workforce; and poor levels of private sector employment of citizens. Consequently, as part of a long-term strategy for efficiency and harmony in human resource management in the region, the examination and implementation of nationalization policies are necessary considerations for governments to redress these socio-demographic imbalances within the labor markets. Based on experiences in the UAE and other GCC states, this paper argues that closer cooperation and unified policy structures in workforce nationalization are necessary among all six GCC states. The key ingredients necessary to achieve the goals of a nationalized labor force include education and training of nationals, the transfer of knowledge from expatriates to citizens, and better approaches for encouraging citizens into the private sector. In particular, a greater effort at encouraging the inclusion of women in the labor force is also required. These initiatives require structural reform in a variety of areas, as well as the coordinated provision of labor and employment policies across the GCC, the implementation of which needs to be varied and distinct from one country to the next. Finally, much depends on the success of current efforts. In order to foster knowledge-based economies across the GCC, service-oriented and hightech industries require a highly skilled labor force as a substitute for the current dependence on hydrocarbon industries.

\section{Background}

Current nationalization efforts seek to redress structural labor shortcomings going back a number of decades. With the widespread discovery of oil in the 1940s and the spread of affluence across Arabian Peninsula societies, jobs requiring various levels of skill were taken up by foreign migrant workers. Across the GCC, rapid economic growth facilitated infrastructure development and the widespread provisions of public goods. In order to support and sustain this growth in the wake of a shortage of supply of native labor, foreign workers-primarily from the Indian 
subcontinent-were invited to fulfill these roles. ${ }^{2}$ Currently, the need to diversify the economy beyond income generation through oil-based revenue has led to a further influx of expatriate workers in the service and construction industries in particular. Debra Johnson states that "the strategy of oil-exporting developing countries... [is] to develop their hydrocarbon industries and utilize the revenues from them to diversify into new economic activities, thereby reducing their over-reliance on this one sector." 3

Over time, a number of GCC countries became dependent on cheaper migrant labor as well as on more qualified Western expatriate labor. In comparison to the relatively wealthy nationals, expatriates have been willing to work longer hours, accept lower wages, and tolerate poorer working conditions as well as more physically demanding jobs. ${ }^{4}$ Consequently, in most GCC countries, over $60 \%$ of the labor force is foreign. ${ }^{5}$ The extent of the demographic imbalance is evident in Table 1.

Table 1. Citizen and Expatriate Statistics Based on Census or Mean Estimated Data

\begin{tabular}{|l|l|l|l|l|l|}
\hline Country & $\begin{array}{l}\text { Total } \\
\text { Population }\end{array}$ & Citizen population & $\begin{array}{l}\text { Citizen as } \\
\text { percentage of } \\
\text { total }\end{array}$ & Expat population & $\begin{array}{l}\text { Expat as } \\
\text { percentage of } \\
\text { total }\end{array}$ \\
\hline Bahrain & 791,000 & 522,049 & 66 & 268,951 & 34 \\
\hline Kuwait & $3,566,437$ & $1,859,437$ & 52 & $1,707,000$ & 48 \\
\hline Oman & $2,845,000$ & $2,267,707$ & 80 & 577,293 & 20 \\
\hline Qatar & $1,696,563$ & 425,563 & 25 & $1,271,000$ & 75 \\
\hline Saudi Arabia & $27,136,977$ & $20,992,741$ & 77 & $6,144,236$ & 23 \\
\hline UAE & $4,106,427$ & 828,427 & 20 & $3,278,000$ & 80 \\
\hline Total (GCC) & $40,142,404$ & $27,646,104$ & 69 & $12,496,300$ & 31 \\
\hline
\end{tabular}

The six nations of the GCC all share an over-reliance on migrant labor; high rates of citizen unemployment; education systems that are still undergoing fundamental development; an inadequate gender balance in the workforce; and poor levels of private sector employment of citizens. Consequently, as part of a long-term

\footnotetext{
${ }^{2}$ Fred Halliday, "Labor Migration in the Middle East," Middle East Research and Information Project Report 59 (1977): 3-17.

${ }^{3}$ Debra Johnson, "EU-Russian Energy Links: A Marriage of Convenience?" Government and Opposition 40, no. 2 (2005): 256-277.

${ }^{4}$ David McMurray, "Recent Trends in Middle Eastern Migration, Trafficking, and Transiting: New Perspectives on Labor Migration," Middle East Report 21, no. 1 (1999): 16-19.

${ }^{5}$ William F. Maloney, "The Structure of Labour Markets in Developing Countries: Time Series Evidence on Competing Views," World Bank working paper (Washington, DC: World Bank, 1998); Elizabeth Ruppert, "Managing Foreign Labour in Singapore and Malaysia: Are there Lessons for GCC Countries?" in World Bank Report (Washington, DC: World Bank, 1998).
} 
strategy for efficiency and harmony in human resource management in the region, the examination and implementation of nationalization policies are necessary considerations for governments to redress these socio-demographic imbalances within the labor markets. As the aspiring knowledge-based economies of the GCC experienced phenomenal growth over the past few decades, GCC governments have recognized that the country's long-term development needs cannot be seconded indefinitely to foreign experts, and must be placed in the hands of a growing national workforce. $^{6}$ This nationalization process is known as Bahrainization in Bahrain, Kuwaitization in Kuwait, Omanization in Oman, Qatarization in Qatar, Saudization in Saudi Arabia, and Emiratization in the United Arab Emirates. ${ }^{7}$

Given their comparatively small populations, the countries of the Arabian Peninsula have experienced particular challenges in the area of human resource management. The default solution has been reliance on importing skilled, semiskilled, and unskilled labor to satisfy the manifold demands of these rapidly growing economies. For the last decade or so, labor nationalization has been seen as a way to counter this growing reliance on imported labor and, more generally, to preserve fledgling national identities. GCC governments have recognized the need to involve nationals in mainstream economic activities along with creating employment opportunities for women in order to further integrate them into the formal economy.

\section{Nationalization and Women in the GCC}

Because oil wealth brought affluence to the Arabian Peninsula, there was an absence of economic necessity for either national men or women to work. This meant that although national males continued to support their households, they opted out of the workforce, and became replaced by growing numbers of migrant laborers. Further, traditional cultural norms and practices ensured the seclusion of women from mainstream economic activities as women were relegated to work within the domestic, household arena. However, in 1937, Kuwait took the lead and instituted a scheme for the education of women. ${ }^{8}$ When the UAE was formed in 1971, it also began educational programs that included women. ${ }^{9}$ Since the 1990s, patterns of economic growth have encouraged the development of a knowledge-based economy, supported by a low rate of illiteracy, access to global information through the Internet,

\footnotetext{
${ }^{6}$ Randeree, "Strategy, Policy, and Practice," 71-91.

${ }^{7}$ Ibid.

${ }^{8}$ Ghada Hashem Talhami, "Women, Education, and Development in the Arab Gulf Countries," The Emirates Occasional Papers no. 53 (United Arab Emirates: The Emirates Center for Strategic Studies and Research, 2004), 16.

${ }^{9}$ Kasim Randeree and Eman Gaad, "Views on the 'Knowledge Economy Project' of the Arabian Gulf: A Gender Perspective from the UAE in Education and Management," The International Journal of Diversity in Organisations, Communities, and Nations 8, no. 2 (2008): 69-77.
} 
and the emergence of well-educated women in corporate leadership positions. ${ }^{10}$ Particularly in the UAE, there has also been a gradual liberalization of social and cultural norms, with similar trends evident in Qatar and Bahrain. In addition, rapid urbanization across the GCC has also had an impact on these changing dynamics. ${ }^{11}$

Across the UAE, the annual employment growth rate averaged $7.9 \%$ up until 2006. Due to the pervasive labor imbalance in the mid-2000s, the government began encouraging Emirati women to enter the workforce, resulting in an average annual increase in female Emirati employment of $16.7 \%$, compared to only $6.1 \%$ for Emirati males. The most recent data on unemployment, published in 2011, indicates that the national unemployment rate in the UAE was $13.8 \%$ of the total national workforce, with $2.0 \%$ of national males and $12.0 \%$ of national females unemployed as a percentage of the total national workforce. ${ }^{12}$

According to a study by the UAE's National Human Resource Development and Employment Authority, TANMIA, Emirati women working in the private sector tend to be young, have comparatively lower education levels, and have comparatively less stable job tenure. ${ }^{13}$ In contrast, Emirati female entrepreneurs were found to be highly educated and independent. ${ }^{14}$ Nevertheless, both female entrepreneurs and those with entry positions voiced general dissatisfaction with the terms and conditions of their employment, the legal and cultural restrictions they face, and the levels of support and assistance they receive from their male peers and supervisors.

In general, the pressure to increase the participation of nationals in the workforce has improved the prospects of employment for women in GCC states. Although nationalization is not the only reason for the movement toward a more equally gendered workforce, it has proven to be significant. As a result, the role of female nationals is manifestly integral to the success of labor nationalization policies. Many studies have indicated that, in some cases, labor nationalization programs, particularly in the UAE, have been constructive in increasing female participation in the workforce. However, further evidence suggests that policies need to be improved and developed in order to place greater emphasis on the important role women play. As such, nationalization institutions need to adopt more gender-focused approaches. ${ }^{15}$

\footnotetext{
${ }^{10}$ Kristin Augsberg, Isabell A. Claus, and Kasim Randeree, Leadership and the Emirati Woman: Breaking the Glass Ceiling in the Arabian Gulf (Berlin: LIT-Verlag, 2009).

${ }^{11}$ Ingo Forstenlechner and Emilie Rutledge, "Growing Levels of National Unemployment in the Arab Gulf: Time to Update the 'Social Contract," Middle East Policy 17, no. 2 (2010): 38-51.

${ }^{12}$ Emilie Rutledge, Fatima Al Shamsi, Yahia Bassioni, and Hend Al Sheikh, "Women, Labour Market Nationalisation Policies and Human Resource Development in the Arab Gulf States," Human Resource Development International 14, no. 2 (2011): 183-193.

${ }^{13}$ Caren Nelson "UAE National Women at Work in the Private Sector: Conditions and Constraints," Centre for Labour Market Research and Information Research Paper no. 20 (Dubai: TANMIA, 2004).

${ }^{14}$ Augsberg et al., Leadership and the Emirati Woman.

${ }^{15}$ Rutledge et al., "Women, Labour Market Nationalisation Policies and Human Resource Development," 183193.
} 


\section{Nationalization in GCC Countries}

State elites throughout the GCC have long recognized that dependence on an expatriate workforce has serious and long-term political, economic, and social implications. ${ }^{16}$ As a result, all countries in the region have developed policies that influence employment practices in public and private sectors, and have initiated steps toward nationalizing their workforces. While nationalization strategies differ from one country to another, they all commonly involve mainstream strategic human resources activities, such as recruitment and selection, education and training, career management, and the design of reward systems. Moreover, nationalization programs are associated with a wide range of considerations, such as competitiveness, globalization, economic growth, and social reform. ${ }^{17}$ Nationalization as a requirement has a two-fold consequence on Human Resource Management (HRM): first in terms of having to adopt multipronged approaches to facilitate nationalization, and, second, having to adapt HRM functions to be operated by nationals. The characteristic challenges faced by HRM in countries interested in encouraging nationalization are to motivate nationals to participate actively in the national economy; to raise skill levels among nationals; and to provide a favorable work environment that enables nationals to recognize and apply their potential.

Given these considerations, it is important to acknowledge that labor nationalization is a long-standing and international issue. While Persian Gulf leaders have devised and implemented nationalization policies specific to their region, parallels can be drawn with employment policies in other regions of the world similarly aimed at subsets of the population. A well-known example is the affirmative action policy in the United States. Although this policy relates to the broad provisions for equality of race, color, religion, sex, and national origin, it has become synonymous with ensuring proportional representation for both AfricanAmerican and female employees in the workplace. Other examples are social inclusion programs, such as those in Australia and Canada. These programs help first nation inhabitants overcome social marginalization by giving them access to employment and education through positive discrimination.

Further, the preference to employ nationals is presented in a study by Richardson and McKenna, which finds that expatriates have very different professional relationships with their employers in their host and home countries. This is manifest through a greater sense of commitment in the home environment

\footnotetext{
${ }^{16}$ Salma M. Al-Lamki, "Barriers to Omanization in the Private Sector: The Perceptions of Omani Graduates," International Journal of Human Resource Management 9, no. 2 (1998): 377-400.

${ }^{17}$ Robert Looney, "Saudization and Sound Economic Reforms: Are the Two Compatible?" Strategic Insights 3, no. 2 (2004): 1-9.
} 
as opposed to the foreign environment provided by their host country. ${ }^{18}$ Examples include a diminished sense of allegiance and loyalty to employers, low expectations for future prospects and promotional opportunities, and a consequential negative impact on performance. The exception to this was found among employees who perceived of themselves archetypally as "dual citizens" despite not having rights to citizenship in their host Persian Gulf country. However, more needs to be done in the workplace to alleviate the sense of foreignness that is perpetuated, with the view that committed employees will be of greater long-term value.

In terms of the broader Middle East, the environment surrounding labor nationalization schemes is characterized by unemployment, soaring birth rates, and the ever-present potential for political instability. Labor nationalization policies in the GCC have similarly been rationalized using variables such as political independence, economic advantages, the conservation of foreign exchange, as well as a nation's desire to manage its own affairs. ${ }^{19}$ For example, Saudization was developed as a result of the political and economic "drawbacks" that have arisen from employing a foreign workforce. ${ }^{20}$ In particular, given the continued tensions and the mutual suspicions among the various regional states, elites often view expatriate workers, especially in industries deemed strategically important, as potential fifth columns and a threat to political domestic stability. As such, labor nationalization efforts are designed not only to redress endemic unemployment or under-employment issues, but they are also often seen as politically prudent and necessary. Below are descriptions of the nationalization policies in all six Gulf Cooperation Council Countries.

\section{The United Arab Emirates}

After the discovery of oil in the UAE and the ensuing economic development, most investment companies imported their workers from outside the UAE due to a lack of local human resources. Due in part to the advanced and comparatively open nature of the UAE's economic development model in relation to most other GCC states, the international community looks to the UAE - and to the city of Dubai in particular - as a model for a new, prosperous Middle East. Throughout the 1990s and the early 2000s, the UAE followed a relatively laissez faire employment policy. As a result, the population of the UAE reached 4.5 million in 2004; of this figure, only $20 \%$ was made up of UAE nationals and the rest comprised of other Arabs, South

\footnotetext{
${ }^{18}$ Julia Richardson and Steve McKenna, "Exploring Relationships with Home and Host Countries: A Study of Self-directed Expatriates," Cross Cultural Management 13, no. 1 (2006): 6.

${ }^{19}$ Christopher J. Rees, Aminu Mamman, and Aysha Braik, "Emiratization a Strategic HRM Change Initiative: Case Study Evidence from a UAE Petroleum Company," The International Journal of Human Resource Management 18, no. 1 (2007): 33-53.

${ }^{20}$ Adel S. Al Dosary, "HRD or Manpower Policy? Options for Government Intervention in the Local Labour Market that Depends upon a Foreign Labour Force: The Saudi Arabian Perspective," Human Resource Development International 7, no. 1 (2004): 123-135.
} 
and Southeast Asians, Europeans, and Americans, among others. ${ }^{21}$ By 2006, 91\% of the country's 2.4 million strong labor force was made up of expatriate workers, leaving a workforce comprised of only $9 \%$ UAE nationals ( $8 \%$ in the public sector and $1 \%$ in the private sector). ${ }^{22}$ In Dubai alone, local citizens accounted for only $2 \%$ of the labor force, while over 50\% were from India (Figure 1). Furthermore, as Table 1 illustrates, both the UAE and Qatar's demographic imbalance between nationals and foreigners tend to be striking not only in the Gulf region, but also globally.

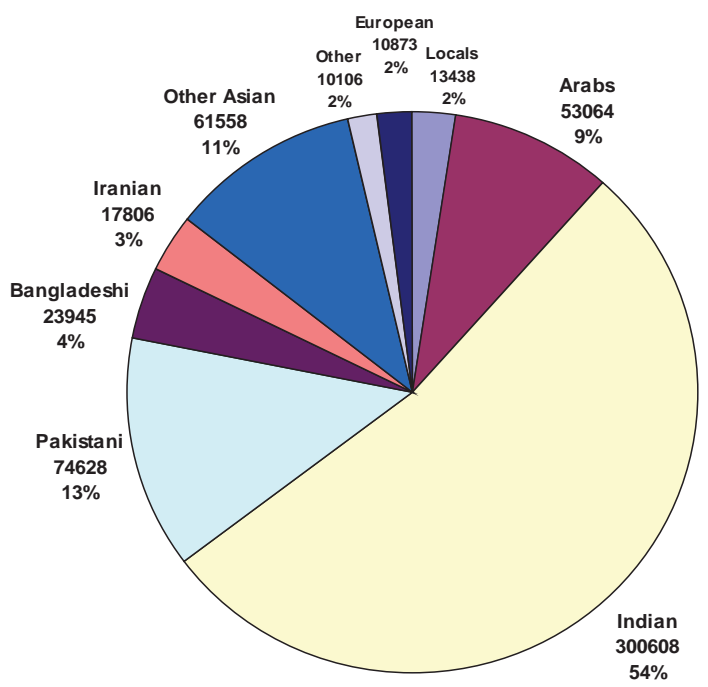

Figure 1. Workforce in Dubai by Nationality (Dubai Government, 2005)

Most UAE nationals are attracted to, and are employed in, the public sector because it offers superior employment conditions, higher remuneration, better job security, shorter working hours, generous vacations, and other attractive options. ${ }^{23}$ Initially, the policy of Emiratization was conducted through structural reform, beginning in the educational sector, rather than through the implementation of specific

\footnotetext{
${ }^{21}$ Jasim Al Ali, "Emiratisation: Drawing UAE Nationals into their Surging Economy," International Journal of Sociology and Social Policy 28, no. 9/10 (2008): 365-379.

22 "Human Resource Report 2005"(Dubai:TANMIA, 2006); Freek Schiphorst, "Voices from the Shop Floor: The Impact of the Multicultural Work Environment on UAE," Centre for Labour Market Research and Information Policy Research Paper no. 11 (Dubai: TANMIA, 2004); Abbas Abdelkarim, and Hans C. Haan, "Skills and Training in the UAE: The Need for and the Dimensions of Institutional Intervention" Centre for Labour Market Research and Information Policy Research Paper no. 5 (Dubai: TANMIA, 2002).

${ }^{23}$ Randeree and Gaad, "Views on the 'Knowledge Economy Project' of the Arabian Gulf," 69-77.
} 
measures. This included education to employment transit programs and funding of the private sector to encourage employment and training of UAE nationals. ${ }^{24}$ In the early 1990s, the UAE Council of Ministers identified employment creation as a top priority and adopted a series of policies aimed at encouraging Emiratization in both public and private sectors. Emiratization falls within the mandate of the Ministry of Labor and Social Affairs, whose responsibilities include employment creation and workforce training. In 1999, the Ministry signed an agreement with the Higher Colleges of Technology (HCT) in order to give top priority to HCT graduates for placement in the public and private sectors. Several web-based services were also established to help various institutions recruit and, at times, train UAE citizens in preparation for entry into the workforce.

Because UAE citizens demand higher salaries, greater benefits, better job security, and shorter working hours than their expatriate counterparts, the private sector has had an increasingly difficult time finding and recruiting qualified Emiratis. Studies that scrutinize the role of private sector employers in the Emiratization process found that challenges to its success could be partly attributed to the attitudes of private sector employers. Significantly, even national employers often have strong reservations about employing fellow nationals for reasons related to hierarchy and prestige. $^{25}$

In terms of female nationals entering the workforce in the UAE, according to a 2003 government study, 96.5\% of students at Abu Dhabi Women's Higher Colleges of Technology said that they wanted to work after graduation, but only $11.5 \%$ favored the private sector. ${ }^{26}$ Due to cultural traditions, many rural UAE national women refuse to work in a mixed-gender environment, and prefer instead to work in female-dominated sectors, such as teaching, or opt to remain unemployed. In this regard, the public sector is more flexible for female employees and so is more attractive.

In order to encourage Emiratization in the private sector and to reduce unemployment among UAE nationals, by the late 1990s, the government stipulated non-mandatory, industry-based quotas. Moreover, policies were issued regarding wage subsidies, wage restraint for government employees, quotas on expatriate labor, and employment targets for UAE nationals. ${ }^{27}$ By the mid-2000s, the government indicated that all secretaries and personnel managers had to be UAE citizens.

\footnotetext{
${ }^{24} \mathrm{Al}$ Ali, "Emiratisation," 365-79.

${ }^{25}$ Ingo Forstenlechner, Mohamed T. Madi, Hassan M. Selim, and Emilie J. Rutledge, "Emiratisation: Determining the Factors that Influence the Recruitment Decisions of Employers in the UAE," The International Journal of Human Resource Management 23, no. 2 (2012): 406-421.

${ }^{26}$ UAE Federal e-Government Portal, http://www.government.ae/gov/ar/index.jsp, accessed May 23, 2011.

${ }^{27}$ Salma M. Al-Lamki, "Omanization: A Three Tier Strategic Framework for Human Resource Management and Training in the Sultanate of Oman," Journal of Comparative Internationals Management 3, no. 1 (2000): 55-75.
} 
Nevertheless, recognizing the multiple challenges involved in locating qualified Emiratis, not to mention enforcing quota targets, the government encouraged private industries to adopt voluntary nationalization quotas and to implement programs aimed at helping young UAE nationals develop their skills. ${ }^{28}$ By 2005, the percentage of UAE nationals in the trade sector had reached only $0.019 \%$, but rose by $2 \%$ in the following year because of penalty enforcement. A year later, it rose to $4 \%$ even without the enforcement of penalties because companies began to realize the tangible benefits of hiring UAE nationals; improved trading relations with others in the sector was a direct consequence of the development of networks brought about through personal contacts among new Emirati employees. ${ }^{29}$ Another cited benefit of employing citizens was the reduced transience of the workforce.

An early major exception to the soft quota system was the banking sector. Given the strategic and developmental role that the banking sector plays in the UAE, banks are an important employer of UAE nationals. As a measure of the importance that the government places on the industry with respect to national human resource development, as early as 1999, an aggressive employment quota system was applied to all banks in the UAE. Up until April 2004, this employment requirement was the only cabinet-imposed quota in the UAE in either the private or the public sectors. In 1999, a Cabinet Decree was issued requiring all banks operating in the country to increase their representation of UAE national employees by $4 \%$ each year. The Human Resource Development Committee in the Banking Sector reports the results of this scheme annually. ${ }^{30}$ By 2003, some $26 \%$ of employees in the 47 independent banks and 454 branches in operation across the seven emirates were Emirati nationals, and $72 \%$ of all banks in the country had achieved their quota targets. ${ }^{31}$

Most Emirati nationals working in the banking sector are employed in Human Resources (HR) roles. The most obvious challenges to Emiratization in the banking and insurance sectors include turnover, salary expectations, retention, recruitment, attitude, and commitment. ${ }^{32}$ Although there were no identifiable qualification barriers to the employment of UAE nationals, by 2005, Emiratization in the sector was just $5.3 \%$ of total employment. ${ }^{33}$ Although Emiratization has not progressed

\footnotetext{
${ }^{28}$ A. Abdul Karim, "Evaluating the Success Factors on Emiratization in the Banking Sector," (MSc Project Management Dissertation, The British University in Dubai, 2009).

${ }^{29}$ Abdul Rahim Sultan, Employer Relations Manager at TANMIA (the National Human Resource Development \& Employment Authority), roundtable discussion by Bayt.com, http://www.ameinfo.com/133128.html, accessed May 31, 2011.

30 "Emiratisation in the Banking Sector: Factors Influencing Success and Failure," Research Paper no. 13, Centre for Labour Market Research and Information Research Paper (Dubai: TANMIA, 2004).

${ }^{31}$ Ibid.

${ }^{32}$ Forstenlechner and Rutledge, "Growing Levels of National Unemployment in the Arab Gulf," 38-51.

33 “Human Resource Report 2005.”
} 
well in recent years, it seems that working conditions and Emiratization-friendly company policies and practices have been gradually improving. This appears to be an important factor in the process. ${ }^{34}$ This finding is supported by a number of studies, which concede that although challenges persist, government initiatives and the use of quotas may have had a positive influence on Emiratization effortseven though the degree of quota enforcement is lower in the UAE than it is in Oman and Saudi Arabia. ${ }^{35}$

Table 2. Dubai Demographic World Records

\begin{tabular}{|l|l|l|}
\hline Parameter & Ratio \% & World Rank \\
\hline Male to female ratio & 2.62 male to 1 female & Highest \\
\hline Workforce to population ratio & $68.33 \%$ & Highest \\
\hline Expats as percentage of population & $82.00 \%$ & Highest \\
\hline Population Growth & $7.00 \%$ & Highest \\
\hline Population under 65 years old & $99.35 \%$ & Highest \\
\hline
\end{tabular}

Source: Madar Research Group, “Dubai Knowledge Economy 2003-2008,” Vol. 2, 2004.

According to the Ministry of Labor, the Emiratization target of 2\% was met by the commercial sector, with $88 \%$ of companies-923 out of 1054 companies in 2006 - meeting their targets and $40 \%$ of companies exceeding their targets. Of these 923 companies, 58\% were in Dubai, 25\% in Abu Dhabi, 13\% in Sharjah, and $4 \%$ in other emirates. In actual numbers, 3,695 Emiratis were recruited in 2006, compared with only 259 Emiratis recruited into the commercial sector in 2005.

A variety of sectors are meeting the challenge and implementing Emiratization policy in the private arena. Since enforcement of quotas in the UAE has been limited to the banking sector, banks are leading the charge in the private sector, driven by a strong strategy for Emiratization. A number of banks have recorded increased Emiratization percentages, achieving an average rate of $34.4 \%$ across all UAE banks by 2010 and representing a steady increase of $4 \%$ on the previous year. Continuing to lead the banking sector in the total proportion of Emirati employees is Sharjah Islamic Bank (SIB), which already had in excess of 50\% Emirati national employees by the beginning of 2007. By early 2010, Abu Dhabi Islamic Bank surpassed 40\%, and Al Hilal Bank achieved 38\%. ${ }^{36}$

\footnotetext{
34 Ibid.

35 "Emiratisation in the Banking Sector;" "Human Resource Report 2005.”

${ }^{36}$ Abu Dhabi Government, "Emiratization in Abu Dhabi," www.abudhabi.ae, accessed January 9, 2012.
} 
Further, the public sector also enables an employee to expand patronage networks and to act as a "wasta"-roughly translated as "connection" or useful intermediary. ${ }^{37}$ Although wasta is often justified as a form of networking, the practice is officially illegal. Organizationally, wasta tends to breed nepotism and often erodes efficiency and levels of technical skill. Not surprisingly, well-qualified GCC nationals often prefer private sector employment-which they find to be professionally more gratifying-over employment in the public sector. ${ }^{38}$ As younger Emiratis prepare to join the workforce, ${ }^{39}$ the next generation needs to acquire the necessary skills to prepare for private sector employment. ${ }^{40}$

The experience of Emiratis in national development and economic growth is similar to neighboring GCC countries. ${ }^{41}$ The UAE shares similar constraints with other GCC countries in terms of the availability of an educated and experienced local workforce. The sociopolitical and socioeconomic circumstances of the UAE during most of the twentieth century, coupled with the lack of modern educational facilities prior to $1971,{ }^{42}$ has resulted in its under development as well as a shortage of educated citizens. ${ }^{43}$ This predicament affects all sectors, but is particularly acute in the private sector, with similar findings across the region. ${ }^{44}$

\section{Saudi Arabia}

Saudi Arabia's population soared from 7 million in 1980 to 21 million in 2003. It currently stands at over 27 million and is estimated to rise by an additional 10 million in $2030 .{ }^{45}$ At the same time, the Kingdom's per capita income dropped from $\$ 17,000$ in the 1980 s to $\$ 8,200$ by 2003 , which is lower than that of other Gulf oil producers. Between 1990 and 2000, the Kingdom's gross domestic product increased by only $1.6 \%$, while the population grew by $2.7 \%$ annually. Unemployment has reached $20 \%$, and a large proportion of Saudi society lives below the poverty line.

\footnotetext{
${ }^{37} \mathrm{Al} \mathrm{Ali}$, "Emiratisation," 365-379.

${ }^{38}$ Abdallah F. Hayajenh, Ahmed S. Maghrabi, and Taher H. Al Dabbagh, "Research Note: Assessing the Effect of Nepotism on Human Resource Management," International Journal of Manpower 15, no. 1 (1994): 60-67.

${ }^{39}$ About $45 \%$ are under the age of 15 .

${ }^{40} \mathrm{Al}$ Ali, "Emiratisation," 365-379; Forstenlechner and Rutledge, "Growing Levels of National Unemployment in the Arab Gulf," 38-51.

${ }^{41}$ Randeree, "Strategy, Policy and Practice," 71-91.

${ }^{42}$ Kasim Randeree and Anjli Narwani, "Managing Change in Higher Education: An Exploration of the Role of Training in ICT Enabled Institutions in the United Arab Emirates," The International Journal of Learning 16, no. 4 (2009): 447-456.

${ }^{43}$ Middle East Research and Information Project (MERIP), 1975.

${ }^{44}$ Gawdat Bahgat, "Education in the Gulf Monarchies: Retrospect and Prospect," International Review of Education/ Internationale Zeitschrift für Erziehungswissenschaft/ Revue Internationale de l'Educatione, 45, no. 2 (1999): 127-136.

${ }^{45}$ Pew Research Center, “The Future of the Global Muslim Population: Projections for 2010-2030” (Washington, DC: Pew Research Center, 2011).
} 
In the second half of the last century, the need for business professionals was crucial, and expatriates were clearly the best option to fill such a gap in terms of education and training. Similar to situations in other GCC countries, due to a shortage of trained nationals outside of the oil industry, the employment of foreign workers to manage high-skilled sectors continues to be a necessity. Al Dosary states that foreign labor in Saudi Arabia is causing an economic drawback as it competes with Saudi labor. ${ }^{46}$ Further, social drawbacks exist due to different cultural values between foreigners and Saudi citizens; psychological and security drawbacks surround fear of a sudden exodus of foreign employees; and there is fear of an absence of knowledge transfer from expatriates to local employees when Saudization laws are implemented. Thus, the idea of Saudization developed from 1995 to 2000 as a series of plans set for one goal: the creation of nearly 319,500 jobs for Saudis through the replacement of foreign workers. The number of expatriates, however, grew by 58,400 during the target period.

With current plans of Saudization, however, Saudi citizens are being introduced gradually into the economy. The Saudization procedure was announced by Saudi Arabia's appointed legislature, the consultative Shura Council, which ordered that $70 \%$ of the country's workforce must be made up of Saudi nationals by 2007. This figure, however, proved too ambitious. By 2011, the Saudi government had developed a more sophisticated system called "Nitaqat," which classified all private sector companies into color-coded bands; red and yellow indicate that the share of foreign workers is too high, and green indicates a high level of success in Saudization. In such a manner, those companies in the green category can hire foreign workers from the other two categories. In turn, red and yellow bands are given restrictions on hiring, including limited term visas for foreign nationals and time constraints for hiring more Saudi nationals. The color banding is based on expectations for Saudization by sector. For example, the requirements ranged from $6 \%$ in the construction sector, to $19 \%$ in media, and $49 \%$ in the banking sector. ${ }^{47}$ This project is underway, and reported outcomes are expected in 2012-2013.

Saudi Arabia is an expanding global market with a high demand for competent employees. With Saudi Arabia joining the World Trade Organization (WTO), the Saudi Arabia General Investment Authority (SAGIA) reported that the level of performance of companies in the Kingdom has to be raised in order to meet international standards, with increased demand for quality performance. Saudi companies are now challenged with meeting higher performance levels with

\footnotetext{
${ }^{46}$ Al Dosary, "HRD or Manpower Policy?" 123-135.

47 "Labor Ministry outlines Saudization percentage," Arab Nerws, www.arabnews.com/saudiarabia/article454198. ece, accessed January 9, 2012.
} 
a workforce that is well-educated, but not well-trained by international standards. In addition, the Saudization policy, with the intent of reducing the number of unemployed Saudi nationals, helps in providing jobs, but not in training or adding to skill and performance levels. ${ }^{48}$ Companies have developed training programs designed to help prepare, train, and promote their employees to be more competent in their current positions and to facilitate their promotion to higher-level positions.

A major challenge is that $60 \%$ of the population in Saudi Arabia is under 20 years old, and Islamic radicalization among unemployed youth remains a great concern. Most children in Saudi Arabia study in Wabhabi schools, where they are instructed in a strictly fundamentalist view of Islam. The educational infrastructure and curriculum does not revolve around competing in a global marketplace in order to move the economy away from dependence on oil. As the Saudi education system depends heavily on rote learning of patriotic and religious texts, students are poorly prepared to join courses that demand technical competence. Between 1995 and 1999 , only $8 \%$ of 120,000 graduates studied technical subjects such as architecture or engineering, which accounts for only $2 \%$ of the total number of Saudis in the job market. ${ }^{49}$ Recognizing this shortfall, the Saudi government has expanded the current higher education infrastructure and built new colleges and universities. Foremost among these is the King Abdullah University of Science and Technology (KAUST); a graduate university founded in 2009 that has received a high level of publicity, both regionally and internationally, largely because of a $\$ 10$ billion endowment from King Abdullah. Consequently, standards are high, and, in its inaugural year, the university was unable to enroll more than one in seven Saudi citizens. ${ }^{50}$

Saudi students also endure longer learning paths in comparison with students in developed nations. ${ }^{51}$ Thus, Saudi graduates need to perform better and faster, and they need more focused training in their early years of employment in order to catch up to their counterparts in other countries. Consequently, there have been calls to overhaul the Saudi education system so that students reach graduation more quickly in order to improve the country's ability to produce qualified workers capable of competing with foreign enterprises.

According to Ian Bremmer, two reasons explain why Saudization has not been very successful so far. First, some businesses have relocated out of the country for fear of losing qualified workers and being forced to hire more expensive, less qualified,

\footnotetext{
${ }^{48}$ Adel S. Al Dosary and Syed Masiur Rahman, "Saudization (Localization) - A Critical Review," Human Resource Development International 8, no. 4 (2005): 495-502.

${ }^{49}$ Ian Bremmer, "The Saudi Paradox," World Policy Journal XXI, no. 3 (2004): 23-30.

${ }^{50}$ Forstenlechner and Rutledge, "Growing Levels of National Unemployment in the Arab Gulf," 38-51.

${ }^{51}$ Al Dosary, "HRD or Manpower Policy?" 123-135; Al Dosary and Rahman, "Saudization," 495-502; Pawan S. Budhwar and Kamel Mellahi, Managing Human Resources in the Middle East (Abindgon: Routledge, 2006); Kamel Mellahi, "The Effect of Regulations on HRM: Private Sector Firms in Saudi Arabia," The International Journal of Human Resource Management 18, no. 1 (2007): 85-99.
} 
and even unskilled Saudi nationals. Second, some foreign firms consider Saudization unpredictable, and they are wary that it may place them at a disadvantage with foreign competitors because rules and quotas for hiring Saudi workers could change without warning. ${ }^{52}$ Companies in Saudi Arabia have varied Human Resources practices with vast differences across industries. ${ }^{53}$ Studies by Budhwar, Mellahi, and Abuljadayel have shown that differences exist in the way Human Resources function in Saudi Arabia and how these policies are actually used and implemented in business sectors. Certain Human Resources practices are problematic, especially in the area of hiring Saudi women as some companies refuse to employ females.

Businesses are finding it extremely difficult to retain high-quality Saudi employees after they have been trained, as the more capable Saudi staff are lured away by better paying companies once they have acquired a higher skill set. Although the public sector is the biggest employer for Saudis at $65 \%$ of the labor force, it still presents a challenge. Since every company in Saudi Arabia must have a fixed percentage of Saudi nationals as part of its workforce, Saudis are often employed in unnecessary positions and are being paid salaries, which amounts to little more than higher levels of inefficiency. ${ }^{54}$

\section{Babrain}

By comparison, Bahrain has a smaller foreign population than neighboring GCC countries, with an expatriate and migrant population of $37.6 \%$, according to the Bahrain Census of 2001. ${ }^{55}$ After the discovery of oil in Bahrain in the late 1930s, an agreement was signed between British and American oil companies and the rulers of Bahrain to give priority to employing Bahraini workers in the Bahrain Petroleum Company (BAPCO). Despite that agreement, most managerial and higher technical positions were filled by British and American professionals. Further, migrants from Iran and the Indian subcontinent filled skilled, semi-skilled, and clerical positions because Bahrainis had little experience or expertise in administrative or industrial labor. Bahrainis were thus minority employees working in BAPCO and a significant number of those officially registered as Bahrainis working for the company were actually Iranian immigrants or their children. ${ }^{56}$ According to Willard A. Beling, by

\footnotetext{
${ }^{52}$ Bremmer, "The Saudi Paradox," 23-30.

${ }^{53}$ Al Dosary and Rahman, "Saudization," 495-502; Budhwar and Mellahi, Managing Human Resources in the Middle East, Sara Nizar Abuljadayel, "Accelerating Human Resource Development in Saudi Arabia," (MSc Project Management Dissertation, The British University in Dubai, 2009); Mellahi, "The Effect of Regulations on HRM," 85-99.

${ }^{54} \mathrm{Al}$ Dosary and Rahman, "Saudization," 495-502.

${ }_{55}$ Onn Winckler, Arab Political Demography: Population Growth and Natalist Policies (Brighton: Sussex Academic Press, 2005).

${ }^{56}$ Ian J. Seccombe and R. I. Lawless, "Foreign Workers Dependence in the Gulf, and the International Oil Companies: 1910-1950," International Migration Review 20, no. 3 (1986): 548-574.
} 
the 1950s, "Westerners [were] in management positions, Indians and Pakistanis in intermediate positions, and Bahrainis at the bottom in lower clerical and labor jobs." ${ }^{57}$ During this period, most Bahrainis worked without official contracts, which resulted in the first and most powerful labor movement in the Gulf. This movement led to the creation of the Bahrain Labor Federation in October 1955, which comprised of 6000 members, and to the drafting of labor legislation for submission to the rulers. ${ }^{58}$

The total number of expatriates increased during the oil boom, and, between 1971 and 1981, the proportion nearly doubled from $17.5 \%$ to $32 \%$ of the population. Bahrain also became a world center of Islamic Banking during this period. ${ }^{59}$ The growth in economic activity produced similar growth in labor needs, resulting in the recruitment of workers from different countries, such as India, Korea, Thailand, and the Philippines. In contrast, the number of Arab migrants decreased sharply along with the number of Iranians, especially after the Islamic Revolution in 1979. Nonetheless, the expatriate share of the workforce increased overall from $37.6 \%$ to 58.8\% between 1971 and $1981 .^{60}$

After spectacular economic growth in the 1970s, Bahrain favored its citizens by providing generous welfare programs, including healthcare provisions and housing. As such, the demand for Bahrainization of the workforce increased ${ }^{61}$ and has focused on four key areas: 1) limiting the supply of foreign workers; 2) creating jobs for Bahrainis; 3) protecting Bahrainis from losing jobs; and 4) reducing unemployment among Bahrainis. ${ }^{62}$

Bahrainization as a policy began in the early 1980s when the government initiated a training and employment scheme called "Project 10,000," which targeted the placement of young Bahrainis in private sector jobs. This was followed in the mid1980s with the introduction of a "Strategic Choices Committee" tasked with finding solutions to the emerging unemployment problems among Bahraini nationals. This marked the first occasion in which labor market issues were addressed as part of a strategic framework that could be labeled as the government's Bahrainization policy. By 1989, this program was further modified and formalized into a five-

\footnotetext{
${ }^{57}$ Willard A. Beling, "Recent Developments in Labor Relations in Bahrayn," The Middle East Journal 13, no. 2 (1959): 156-169.

${ }^{58}$ M. G. Rumaihi, Bahrain: Social and Political Change since the First World War (London: Bowker/Centre for Middle Eastern and Islamic Studies of the University of Durham, 1976); Emile Nakhleh, Bahrain: Political Development in a Modernizing Society (Lexington, MA: Lexington Books, D.C. Health Company, 1976).

${ }^{59}$ Beverly Dawn Metcalfe, "Exploring Cultural Dimensions of Gender and Management in the Middle East," Thunderbird International Business Review 48, no. 1 (2006): 93-107.

${ }^{60}$ Laurence Louë, “The Political Impact of Labor Migration in Bahrain," City E Society 20, no. 1 (2008): 32-53.

${ }^{61}$ Nakhleh, Babrain.

${ }^{62}$ Mohammed Dito, "Migration Policies and Challenges in the Kingdom of Bahrain," (paper presented at the Migration and Refugee Movements in the Middle East and North Africa, The American University in Cairo, Egypt, October 23-25, 2007).
} 
year Bahrainization plan formulated on a structured process for the creation of new jobs in different economic sectors. Following this five-year plan, in 1994, the Bahrainization percentage law was issued and forecasted that a 5\% annual increase of Bahrainis in the private sector could alleviate unemployment. By 2001, a new project for training and employing 4,000 Bahrainis was launched by the Ministry of Labor and Social Affairs, which combined employee training programs with wage subsidies for employers who placed Bahraini citizens in their companies. ${ }^{63}$

The public sector became the prime employer for Bahraini nationals where the jobs were not demanding and were well-paid compared to the private sector. While the public sector recruited Bahrainis, the private sector recruited foreigners to fill almost all of the newly created jobs. In 1981, Bahrainis represented 33\% of the private sector workforce and $67 \%$ of the public sector workforce. ${ }^{64}$ Data for 20022006 demonstrates that Bahrainis represented 29\% of the private sector workforce, which is a decline of only $4 \%$ from two decades earlier. In contrast, $91 \%$ of the total public sector workforce was Bahraini, denoting a significant increase of $24 \%$ from the 1981 data. This increase clearly indicates that Bahrainization has been accelerating rapidly in the public sector, whereas issues remain as to how to tackle the problem in the private sector. ${ }^{65}$

In summary, as with policies across the GCC region, the government of Bahrain has continually modified its nationalization policies in recent decades. These varying policies and programs, although well-meaning in their attempts to find jobs for Bahrainis, have largely been unsuccessful because of overriding market forces.

\section{Kuwait}

At the time of Kuwait's first census in 1957, Kuwaitis constituted $55 \%$ of the country's total population. This figure decreased to $42 \%$ by 1980 , and to about $40 \%$ by 1985 . In 1980, Kuwaitis made up less than a quarter of the total labor force due to accelerated levels of immigration. The country had thus developed an extreme level of dependency on foreign workers. Kuwait had fewer than one million people in 1975, which increased to 1.35 million in 1980 and to 1.7 million in 1985 . These increases were due, for the most part, to the influx of migrant workers. ${ }^{66}$

\footnotetext{
${ }^{63}$ The British Council, "Employer Engagement and Occupational Standards,"www.britishcouncil.org/tvetarabiabahrain-employer-engagement-and-occupational-standards.htm, accessed January 9, 2012.

${ }^{64}$ Rob Franklin, "Migrant Labor and the Politics of Development in Bahrain," Middle East Research and Information Project Report no. 132, 1985.

${ }^{65}$ Emilie Rutledge, Monetary Union in the Gulf: Prospects for a Single Currency in the Arabian Peninsula, (London: Routledge, 2009).

${ }^{66}$ Nasra M. Shah, "Foreign Workers in Kuwait: Implications for the Kuwaiti Labor Force," International Migration Review 20, no. 4 (1986): 1-18.
} 
Currently in Kuwait, foreign nationals comprise $52 \%$ of the population (as seen in Table 1) and $78 \%$ of the labor force ${ }^{67}$ As for Kuwaiti citizens, $62 \%$ of Kuwaiti males are employed in public sector administrative and social occupations, whereas their percentage in private sector sales and production work has been on the decline since the 1970s.

When Kuwaitization began in 1978, nearly half of the Kuwaiti population was under 15 years old and economic activity was the lowest of any Arab country. ${ }^{68}$ The Kuwaitization process aimed to balance the national and foreign workforce ratio not only by providing educational/training programs as is the norm across the GCC, but also by changing Kuwaitis' attitudes towards manual work. Although scholarly work on Kuwaitization and associated policy is scarce-only a few published articles examining the issue in the past 25 years-secondary sources indicate that current policy and outcomes are not dissimilar to other Gulf nations. Kuwait experiences difficulties in private sector employment; good public sector representation; a focus on stipulating national work force percentages; limitations on the issuance of work permits for new foreign laborers; positive action on female citizen participation in the workforce; a national work force restructuring program; and training programs to equip citizens to take up positions in the private sector.

Kuwaitization commenced with very rigid directives that only permitted single-status foreign workers to enter Kuwait without family members; expatriate workers were to be replaced with Kuwaitis whenever possible; and more capitalintensive technology was to be imported in order to reduce dependence on foreign employees. ${ }^{69}$ By 1997, however, the policy had matured and the Manpower and Government Restructuring Program (MGRP) was established with the aim of redistributing Kuwaiti employees in a more balanced manner across public and private sectors. This policy included quotas based on sector of activity in nongovernmental industries. By 2008, 60\% Kuwaitization was required for banks, $15 \%$ for the real estate sector, and $2 \%$ for manufacturing industries, as outlined in Ministerial Decree 1104. This policy was followed by an enactment of the National Assembly's law number 19/2000, which stipulated that additional allowances be paid to Kuwaiti professionals in private sector organizations and that there should also be further incentives for employers. According to MGRP statistics, unemployment among Kuwaiti nationals has been steadily declining, falling from $8.5 \%$ in 2000 to $4.9 \%$ in 2010 , and the public/private sector imbalance is being alleviated, albeit at a slow pace.

\footnotetext{
${ }^{67}$ Ibid.
}

${ }^{68}$ D. Hosni and I. Sirageldin, "The Dynamics of Manpower in Kuwait: A Dilemma for a Petroleum-Exporting Country," Tiers Monde 26, no. 103 (1985): 621-635.

${ }^{69}$ Mostafa H. El-Shalakani, Amal Y. A. El-Sabah, and Mahmoud A. Iskander, "An Optimized Model for Substitution of Expatriate Workforce in a Gulf-Council Country: The Kuwaiti Case," International Migration 34, no. 2 (1996): 273-295. 


\section{Qatar}

Qatar has experienced high economic growth over the past five years, and is now the richest country in the world measured in GDP per capita at an estimated $\$ 88$, 221 in $2010 .^{70}$ The closest estimation of the population of Qatar is around 1.7 million, of which $25 \%$ is made up of Qatari citizens, and the remaining $75 \%$ are expatriates of different nationalities (as seen in Table 1). This figure is extremely variable depending on the source, but it represents a mean based on a dataset derived from Qatari government census information, the CIA World Factbook, World Bank statistics, and Qatari and Gulf press estimates. Many expatriates in Qatar are long-term residents, with the largest communities hailing from India, Pakistan, and Bangladesh.

Based on the Economist Intelligence Unit's forecasts, Qatar's economy is expected to return to its high performing standard, where prior to the global crisis its economic growth reached 9\%. Qatar has invested heavily in education, health, construction, and infrastructure projects, resulting in high long-term macroeconomic growth and political stability. ${ }^{71}$ The oil and gas industry is the most productive sector in Qatar's economy, and while Qatar has very little oil, it has vast Liquid Natural Gas (LNG) reserves and substantial investment has been undertaken in this industry. This sector is followed by the financial services sector. Future investments will begin to demonstrate a positive impact on Qatari employment, albeit to a limited extent, as more investment becomes concentrated in service sectors, such as finance and energy services. Examples of such investments include Qatar Financial Center (QFC) established in 2005, and Energy City Qatar (ECQ), which is still under construction with an expected completion date of 2012. According to the Qatar Labor Market Strategy, however, only 25,000 jobs in the private sector are currently acceptable to Qataris.

It is characteristic that $96 \%$ of Qataris are employed in either public or mixed public and private sectors, and only 4\%-reduced from 10\% in 1986-are employed in the private sector. ${ }^{72}$ This is due to the various benefits and flexible working conditions afforded to Qataris in the public sector. Moreover, the average wage for employees per month in June 2005 was QR 3558 (\$975) in the private sector, QR $9139(\$ 2,504)$ in the public sector, and QR $11152(\$ 3,055)$ in the mixed public/ private sector. Around 50,000 Qataris are employed in the public sector, although the overall Qatari/non-Qatari ratio in the total labor force is 1 to 8 .

\footnotetext{
70 "Qatar Now World's Richest Nation, Says IMF," Arabian Business, www.arabianbusiness.com/qatar-nowworld-s-richest-nation-says-imf-421787.html, accessed January 31, 2012.

${ }^{71}$ Government of Qatar - Planning Council, "Turning Qatar into a Competitive Knowledge-Based Economy: Knowledge Economy Assessment of Qatar," Qatar Knowledge Economy Project (Doha: Government of Qatar, 2007) 5 .

${ }^{72}$ Ibid, 4.
} 
The overall rate of employment for Qataris increased from 93\% in 1986 to 98\% in 2004. In contrast, the average unemployment rate is very low compared to the percentage of the total labor force, which is around 1.4\%. Unemployment, however, can be a problem for less educated and young graduates who cannot find a job in the already saturated public sector. One of the problems that Qatarization is facing is the low rate of competition in the labor market in terms of public/private, national/ expatriate, and male/female, which has caused low mobility and an ineffective allocation of supply and demand for skills.

Further, education is not as appealing to male Qataris as it is to female Qataris. Statistically, female workers have 14.1 years of education compared to 10.7 years for male workers. Education and training institutions are highly disparate in Qatar, with no mechanism for cooperation among them. Furthermore, most training centers lack human and financial resources, resulting in a weak strategy for workforce development in the country. Qatar is, however, in the process of developing a National Qualification Framework to improve vocational education and post-compulsory training, ${ }^{73}$ and recent investments have attempted to transform the education sector by placing greater emphasis on English instruction and vocational subjects in the sciences. In addition, Qatar has established "Education City" — an initiative of the Qatar Foundation for Education, Science and Community Development-which has attracted prestigious U.S. and European universities to participate in the project. ${ }^{74}$

\section{Oman}

National development of the Sultanate of Oman and its labor experience is similar to other GCC countries, although the impact of foreign labor on Oman has been significantly less by comparison. With the exception of Bahrain, Oman has significantly less oil and gas reserves compared to other GCC states. It also has one of the lowest GDP per capita in the region. As a result, the nationalization process has been much more extensive and far more successful than in other GCC state. ${ }^{75}$

The Sultanate of Oman began its Omanization strategy in 1988. According to Al-Lamki, the total workforce's national profile in Oman showed that only $18.2 \%$ was Omani and $81.8 \%$ was expatriate labor in $1998 .{ }^{76}$ In order to advance Omani society, after Sultan Qaboos Bin Said took power, he issued policies supported by oil revenues. Thus, Omani society witnessed social and economic development, resulting in the government's importation of foreign manpower primarily from the Indian sub-continent.

\footnotetext{
${ }^{73}$ Government of Qatar, "Turning Qatar into a Competitive Knowledge-Based Economy."

${ }^{74}$ Forstenlechner and Rutledge, "Growing Levels of National Unemployment in the Arab Gulf," 38-51.

${ }^{75}$ Ibid.

${ }^{76}$ Al-Lamki, “Omanization,” 55-75
} 
Prior to 1970, Oman faced a shortage of indigenous educated people due to a lack of modern educational facilities. ${ }^{77}$ The country experienced major challenges during the process of developing and training Omani people as there were only three elementary schools for boys-the only source for modern education. As in other GCC countries, the government established several federal universities to train Omani workers. ${ }^{78}$ More recently, an increased number of educated and trained Omanis are beginning to replace existing expatriates in the workforce.

The Committee for Vocational Training issued a decision in 1991 to increase the Omanization percentage within a specific time-period for different employment sectors in the country, with a focus on the private sector. The committee was supported by a number of Omanization schemes and initiatives, such as a tailored compensation scheme for the private sector as well as salaries and allowances payable to Omanis during the training period..$^{79}$

Further, the government set quotas for industries to employ a percentage of Omani nationals instead of foreign workers. The quotas in the transport, storage, and communication sectors were set to reach $60 \%$ of the total employed workforce. For finance, insurance, and real estate, the figure was $45 \%$. In addition, the national workforce percentage was set to reach $35 \%$ in industries, $30 \%$ in hotels and restaurants, and $20 \%$ in wholesale and retail trading. Companies that successfully reach their government quota targets are given a "green card" that enables them to receive press attention and preferential treatment in their dealings with the government. To date, many government ministries have already achieved 100\% Omanization.

\section{Conclusion}

Although research is clearly increasing in the area of nationalization of GCC labor, currently available literature remains limited. According to Rees et al., ${ }^{80}$ in August 2005, an internet search for the words Emiratization, Omanization, and Saudization resulted in 38,000,12,000, and 24,000 hits respectively. Using the same terms in a general database of international academic business and management literature resulted in no published papers for the term Emiratization, and only two papers for Saudization and Omanization. Clearly, there is a need for further research in this area, taking into account the effect on business performance, human resource development, and the continuity of GCC business as a whole.

\footnotetext{
${ }_{77}$ Al-Lamki, "Omanization," 55-75; John Townsend, Oman: The Making of a Modern State (London: CroomHelm, 1977).

${ }^{78}$ Kailash Chandra Das and Nilambari Gokhale "Localization of Labor and International Migration: A Case Study of the Sultanate of Oman," (paper presented at the XXVI International Population Conference of the IUSSP, Marrakech, September 27 to October 2, 2009).

${ }^{79}$ Al-Lamki, "Omanization," 55-75; Townsend, Oman.

${ }^{80}$ Rees et al., "Emiratization a Strategic HRM Change Initiative," 33-53.
} 
Success of nationalization schemes could be attributed to very basic decisions taken long before Human Resource processes became relevant. Ingo Forstenlechner identifies two main ways of discussing nationalization in the UAE: 1) as an effort geared at producing statistics for Public Relations, or 2) as a serious commitment to the integration of nationals into the workforce. ${ }^{81}$ Forstenlechner suggests that the choice between these two would determine the future success of nationalization. Clearly, for nationalization processes to be successful in GCC countries, the focus must be on improving the education system and training the resultant workforce. In contrast, a sector or position based quota system where penalties are given for non-compliance are simply ineffective as a long-term strategy and result in poorly qualified and inexperienced personnel.

Attracting GCC national employees is one of the greatest organizational development challenges facing the private sector in all GCC states. Currently, most GCC nationals prefer to seek employment in the public sector because of better conditions, higher salaries, shorter working hours, greater job security, and more comprehensive employment packages. ${ }^{82}$ However, it is gradually becoming evident in private industry that there is government commitment to an articulated strategic nationalization plan, a long-term vision for nationalization, as well as acknowledgement of the role and importance of foreign participants.

Even with such a concerted effort, challenges remain. In order for sustained development of a national workforce, organizations would be best served by national employees beginning at entry-level positions and working their way through the organizational hierarchy. Thus, when they reach the boardroom level, they have gained significant experience, resulting in better decision-making through an understanding of the organization as a whole. Another area that requires improvement is encouraging citizens to enter into semi-skilled positions, such as taxi drivers or petrol pump attendants. These and other vocations have been notably successful in the Sultanate of Oman and are reflected in successful Omanization process statistics. Nationals are gradually filling other seemingly undesirable positions such as retail cashiers. This has been successfully demonstrated in the UAE by the employment practices of the international hypermarket retail chain Carrefour.

\footnotetext{
${ }^{81}$ Ingo Forstenlechner, "Workforce Nationalization in the UAE: Image versus Integration," Education, Business and Society: Contemporary Middle Eastern Issues 1, no. 2 (2008): 82-91.

${ }^{82}$ Kasim Randeree and Abdul Ghaffar Chaudhry, "Leadership in Project Managed Environments: Employee Perceptions of Leadership Styles within Infrastructure Development in Dubai," International Review of Business Research Papers 3, no. 4 (2007): 220-232.
} 
The current reality is that although citizens are now better educated than they were in the past, they are not prepared professionally for the senior positions reserved for them. ${ }^{83}$ Education alone does not adequately prepare citizens for management decision-making roles, and this lack of preparation consequently reflects in poor organizational performance.

Women in Gulf societies have come a very long way toward achieving full equality. Yet, although their employment statistics have increased markedly in recent decades (Table 3), societal attitudes need to change further if these results can be seen as anything more than merely a statistical increase in the number of women in the workforce. Although women are still deterred-perhaps not by policy but by culture-from certain positions such as the armed forces or the police force, Gulf women have made great strides in the workplace compared to a generation ago. However, more has to be done to support the understanding that equal opportunity is more than a courtesy; it is the right of all citizens. Many in Gulf communities still need to be educated to the fact that women are fully functional members of society. ${ }^{84}$

Table 3. Women in the GCC Workforce (Percentage of Total Waged Workforce), 1975-2000

\begin{tabular}{|l|l|l|l|}
\hline Country & $\mathbf{1 9 7 5}$ & $\mathbf{1 9 8 0}$ & $\mathbf{2 0 0 0}$ \\
\hline Bahrain & 5 & 11 & 21 \\
\hline Kuwait & 8 & 13 & 31 \\
\hline Oman & - & 6 & 17 \\
\hline Qatar & 2 & 7 & 15 \\
\hline Saudi Arabia & 5 & 8 & 16 \\
\hline UAE & 3 & 5 & 15 \\
\hline
\end{tabular}

Source: J. Willoughby, "Segmented Feminization and the Decline of Neopatriarchy in GCC Countries of the Persian Gulf,” Comparative Studies of South Asia, Africa, and the Middle East 28, no.1 (2008): 184-199.

Even so, the greater participation of women presents a double-edged sword to nationalization policies. Similar to situations in Europe and North America, rising female employment affects national birthrate, which in turn creates sustainability problems in the labor force for the coming generation (Table 4). While immigration

\footnotetext{
${ }^{83}$ Emirates 24/7, "Expats Fear Others May Follow KSA's Visa Limit: New Programme to Force Saudi Firms to Cut Expatriate Workforce and Hire Local Citizens," www.emirates247.com/news/region/expats-fear-othersmay-follow-ksa-s-visa-limit-2011-05-31-1.399404, accessed January 31, 2012.

${ }^{84}$ Janette Webb, “The Politics of Equal Opportunity," Gender, Work and Organization 4, no. 4 (1997): 159; Augsberg et al., Leadership and the Emirati Woman.
} 
policies in the West can, to a great extent, cope with this, the GCC has a unique set of challenges that put it in a more precarious position when it comes to sustainability issues.

Table 4. Decline in Fertility Rates in the GCC Between 1980 and 2000 Among All Female Inhabitants

\begin{tabular}{|l|l|l|l|}
\hline Country & Births per woman 1980 & Births per woman 2000 & Decline in fertility (\%age) \\
\hline Bahrain & 5.2 & 2.8 & 46.2 \\
\hline Kuwait & 5.3 & 2.7 & 49.1 \\
\hline Oman & 9.9 & 4.3 & 56.6 \\
\hline Qatar & 5.6 & 2.6 & 46.4 \\
\hline Saudi Arabia & 7.3 & 5.5 & 24.7 \\
\hline UAE & 5.4 & 3.2 & 40.7 \\
\hline
\end{tabular}

Source: J. Willoughby, "Segmented Feminization and the Decline of Neopatriarchy in GCC Countries of the Persian Gulf,” Comparative Studies of South Asia, Africa, and the Middle East, 28(1), (2008): 184-199.

The GCC region is facing significant problems related to rising rates of unemployment among nationals in a climate of slowing economic growth and increasing reliance on foreign labor. ${ }^{85}$ Evidence clearly suggests that for prospective knowledge-based economies in the GCC region to succeed, they must first utilize all of their human resources and encourage increased participation of women in the workplace. ${ }^{86}$ There needs to be continuous reform efforts made regarding female employment opportunities. Gulf societies' attitudes towards a growing, educated female population, ignored and underutilized in the workforce for cultural or historic reasons, remains a hindrance.

This study highlights the fact that gender is not the only issue where the six nations share common problems, and recommends that all GCC countries work more closely and efficiently in order to address their mutual difficulties. In line with this, regional governments favor a three-pronged strategy: to improve the mobility of all workers, including expatriates; to advance the productivity of GCC citizens whereby

\footnotetext{
${ }^{85}$ Bruce Q. Budd, "An Overview of the Demographic and Labour Trends of the Member Nations of the Cooperation Council for the Arab States of the Gulf," Centre for Labour Market Research and Information Research Paper no. 10 (Dubai: TANMIA, 2002).

${ }^{86}$ Kasim Randeree, "The Impact of Historical and Cultural Effects on the Advancement of Women in the K-Economy in the Arabian Gulf Region: Participation of Women in the Arabian Gulf," International Journal of Knowledge, Culture and Change Management 6, no. 1 (2006): 65-68.
} 
no job is considered off limits and citizens can compete with foreign nationals on a level playing field; and to integrate the output of educational establishments with the needs of the labor market. All of these measures are designed to create authentic nationalization processes in GCC states. 


\section{BIBLIOGRAPHY}

Abdalla, I. "Attitudes towards Women in the Arabian Gulf Region." Women in Management Review 11, no. 1, (1996): 29-39.

Abdelkarim, Abbas, and Hans C. Haan. "Skills and Training in the UAE: The Need for and the Dimensions of Institutional Intervention." Centre for Labour Market Research and Information Policy Research Paper no. 5. Dubai: TANMIA 2002.

Abdul Karim, A. "Evaluating the Success Factors on Emiratization in the Banking Sector." MSc Project Management Dissertation, The British University in Dubai 2009.

Abu Dhabi Government. "Emiratization in Abu Dhabi." www.abudhabi.ae.

Abuljadayel, Sara Nizar. "Accelerating Human Resource Development in Saudi Arabia." MSc Project Management Dissertation, The British University in Dubai, 2009.

Al Ali, Jasim. "Emiratisation: Drawing UAE Nationals into their Surging Economy." International Journal of Sociology and Social Policy 28, no. $9 / 10$ (2008): 365-379.

Al Dosary, Adel S. "HRD or Manpower Policy? Options for Government Intervention in the Local Labour Market That Depends Upon a Foreign Labour Force: The Saudi Arabian Perspective." Human Resource Development International 7, no. 1 (2004): 123-135.

A1 Dosary, Adel S., and Syed Masiur Rahman. "Saudization (Localization) —A Critical Review." Human Resource Development International 8, no. 4 (2005): 495-502.

Al-Lamki, Salma M. "Barriers to Omanization in the Private Sector: The Perceptions of Omani Graduates." International Journal of Human Resource Management 9 , no. 2 (1998): 377-400.

- "Omanization: A Three Tier Strategic Framework for Human Resource Management and Training in the Sultanate of Oman." Journal of Comparative International Management 3, no. 1 (2000): 55-75.

Al-Qudsi, Sulayman S. "Unemployment Evolution in the GCC Economies: Its Nature and Relationship to Output Gaps." Centre for Market Research and Information, Labor Market Study no. 22. Dubai: TANMIA, 2006.

Arab Nerws. "Labor Ministry outlines Saudization percentage." www.arabnews.com/ saudiarabia/article454198.ece. 
Arabian Business. "Qatar NowWorld's Richest Nation, Says IMF.” www.arabianbusiness. com/qatar-now-world-s-richest-nation-says-imf-421787.html.

Augsberg, Kristin, Isabell A. Claus, and Kasim Randeree. Leadership and the Emirati Woman: Breaking the Glass Ceiling in the Arabian Gulf. Berlin: LIT-Verlag, 2009.

Bahgat, Gawdat. "Education in the Gulf Monarchies: Retrospect and Prospect." InternationalReviewof Education/Internationale Zeitschrift fürErziehungswissenschaft/ Revue Internationale de l'Education 4, no. 2 (1999): 127-136.

Beling, Willard A. "Recent Developments in Labor Relations in Bahrayn.” The Middle East Journal 13, no. 2 (1959): 156-169.

Bremmer, Ian. “The Saudi Paradox.” World Policy Journal XXI, no. 3 (2004): 23-30.

British Council. "Employer Engagement and Occupational Standards." www. britishcouncil.org/tvetarabia-bahrain-employer-engagement-andoccupational-standards.htm.

Budd, Bruce Q. "An Overview of the Demographic and Labour Trends of the Member Nations of the Cooperation Council for the Arab States of the Gulf." Working Paper Series no. 10, Centre for Labour Market Research and Information. Dubai: TANMIA, 2002.

Budhwar, Pawan S., and Kamel Mellahi. Managing Human Resources in the Middle East. Abingdon: Routledge, 2006.

Das,Kailash Chandra, and Nilambari Gokhale."Localization of Labor and International Migration: A Case Study of the Sultanate of Oman.” XXVI International Population Conference of the IUSSP. Marrakech: 2009.

Dito, Mohammed. "Migration Policies and Challenges in the Kingdom of Bahrain." The Forced Migration and Refugee Studies Program Working Paper. Egypt: The American University in Cairo, 2007.

El-Shalakani Mostafa H., Amal Y. A. El-Sabah, and Mahmoud A. Iskander. "An Optimized Model for Substitution of Expatriate Workforce in a Gulf-Council Country: The Kuwaiti Case." International Migration 34, no. 2 (1996): 273-295.

Emirates 24/7. "Expats Fear Others May Follow KSA's Visa Limit: New Programme to Force Saudi Firms to Cut Expatriate Workforce and Hire Local Citizens." www.emirates247.com/news/region/expats-fear-others-may-follow-ksa-svisa-limit-2011-05-31-1.399404. 
Forstenlechner, Ingo. "Workforce Nationalization in the UAE: Image versus Integration." Education, Business and Society: Contemporary Middle Eastern Issues 1, no. 2 (2008): 82-91.

Forstenlechner,Ingo, and Emilie Rutledge. "Growing Levels of NationalUnemployment in the Arab Gulf: Time to Update the 'Social Contract." Middle East Policy 17, no. 2 (2010): 38-51.

Forstenlechner, Ingo, Mohamed T. Madi, Hassan M. Selim, and Emilie J. Rutledge. "Emiratisation: Determining the Factors that Influence the Recruitment Decisions of Employers in the UAE." The International Journal of Human Resource Management 23, no. 2 (2012): 406-421.

Franklin, Rob. "Migrant Labor and the Politics of Development in Bahrain." Middle East Research and Information Project Report no. 132 (1985): 7-13.

Government of Qatar-Planning Council. "Turning Qatar into a Competitive Knowledge-Based Economy: Knowledge Economy Assessment of Qatar." Doha: Government of Qatar, 2007.

Halliday, Fred. "Labor Migration in the Middle East." Middle East Research and Information Project Report no. 59 (1977): 3-17.

Hayajenh, Abdallah F., Ahmed S. Maghrabi, and Taher H. Al-Dabbagh. "Research Note: Assessing the Effect of Nepotism on Human Resource Management." International Journal of Manpower 15, no. 1 (1994): 60-67.

Hosni D., and I. Sirageldin. "The Dynamics of Manpower in Kuwait: A Dilemma for a Petroleum-Exporting Country.” Tiers Monde 26, no. 103 (1985): 621-635.

Hourani, Albert. A History of the Arab Peoples. London: Faber \& Faber, 1991.

International Monetary Fund. "The Cooperation Council of the Arab States of the Gulf (GCC): Strategy for Sustainable Growth with Macroeconomic Stability." Washington, DC: International Monetary Fund, 2001.

Johnson, Debra."EU-Russian Energy Links: A Marriage of Convenience?" Government and Opposition 40, no. 2 (2005): 256-277.

Looney, Robert. "Saudization and Sound Economic Reforms: Are the Two Compatible?" Strategic Insights 3, no. 2 (2004): 1-9.

Louër, Laurence. “The Political Impact of Labor Migration in Bahrain." City E̋ Society 20, no. 1 (2008): 32-53. 
Madar Research Group. “Dubai Knowledge Economy 2003-2008.” Dubai: Madar Research Group, 2004.

Maloney, William F. "The Structure of Labour Markets in Developing Countries: Time Series Evidence on Competing Views." World Bank Working Paper, Washington, DC: World Bank, 1998.

McMurray, David. "Recent Trends in Middle Eastern Migration, Trafficking and Transiting: New Perspectives on Labor Migration.” Middle East Report 21, no. 1 (1999): 16-19.

Mellahi, Kamel. "The Effect of Regulations on HRM: Private Sector Firms in Saudi Arabia." The International Journal of Human Resource Management 18, no. 1 (2007): 85-99.

Metcalfe, Beverly Dawn. "Exploring Cultural Dimensions of Gender and Management in the Middle East." Thunderbird International Business Review 48, no. 1 (2006): 93-107.

Middle East Strategy Advisors. "Migrating from UAE Nationalization to Skill-Based UAE Nationalization.” Dubai: Middle East Strategy Advisors, 2006.

Nakhleh, Emile A. Babrain: Political Development in a Modernizing Society. Lexington MA: Lexington Books, D.C. Health Company, 1976.

Nelson, Caren. "UAE National Women at Work in the Private Sector: Conditions and Constraints." Centre for Labour Market Research and Information Research Paper no. 20. Dubai: TANMIA, 2004.

Pew Research Center. "The Future of the Global Muslim Population: Projections for 2010-2030.”Washington, DC: Pew Research Center, 2011.

Randeree, Kasim. “The Impact of Historical and Cultural Effects on the Advancement of Women in the K-Economy in the Arabian Gulf Region: Participation of Women in the Arabian Gulf." International Journal of Knowledge, Culture, and Change Management 6, no. 1 (2006): 65-68.

."Strategy, Policy, and Practice in the Nationalization of Human Capital: 'Project Emiratization." Research and Practice in Human Resource Management 17, no. 1 (2009): 71-91.

Randeree, Kasim, and Abdul Ghaffar Chaudhry. "Leadership in Project Managed Environments: Employee Perceptions of Leadership Styles within Infrastructure Development in Dubai." International Review of Business Research Papers 3, no. 4 (2007): 220-232. 
Randeree, Kasim, and Eman Gaad. "Views on the 'Knowledge Economy Project' of the Arabian Gulf: A Gender Perspective from the UAE in Education and Management." The International Journal of Diversity in Organisations, Communities, and Nations 8, no. 2 (2008): 69-77.

Randeree, Kasim, and Anjli Narwani."Managing Change in Higher Education: An Exploration of the Role of Training in ICT Enabled Institutions in the United Arab Emirates." The International Journal of Learning 16, no. 4 (2009): 447-456.

Rees, Christopher J., Aminu Mamman, and Aysha Braik. "Emiratization a Strategic HRM Change Initiative: Case Study Evidence from a UAE Petroleum Company." The International Journal of Human Resource Management 18 no. 1 (2007): 33-53.

Richardson, Julia, and Steve McKenna. "Exploring Relationships with Home and Host Countries: A Study of Self-directed Expatriates." Cross Cultural Management 13, no. 1 (2006): 6-22.

Rumaihi, M.G. Bahrain: Social and Political Change since the First World War. London: Bowker/Centre for Middle Eastern and Islamic Studies of the University of Durham, 1976.

Rutledge, Emilie. Monetary Union in the Gulf: Prospects for a Single Currency in the Arabian Peninsula. London: Routledge, 2009.

Rutledge, Emilie, Fatima Al Shamsi, Yahia Bassioni, and Hend Al Sheikh. "Women, Labour Market Nationalisation Policies and Human Resource Development in the Arab Gulf States." Human Resource Development International 14, no. 2 (2011): 183-193.

Ruppert, Elizabeth. "Managing Foreign Labour in Singapore and Malaysia: Are There Lessons for GCC Countries?” In World Bank Report. Washington DC: World Bank, 1998.

Schiphorst, Freek. "Voices from the Shop Floor: The Impact of the Multicultural Work Environment on UAE.” Centre for Labour Market Research and Information Policy Research Paper no. 11. Dubai: TANMIA, 2004.

Seccombe, Ian J., and R. I. Lawless. "Foreign Workers Dependence in the Gulf, and the International Oil Companies: 1910-1950.” International Migration Review 20, no. 3 (1986): 548-574.

Shah, Nasra M. "Foreign Workers in Kuwait: Implications for the Kuwaiti Labor Force.” International Migration Review 20, no. 4 (1986): 1-18. 
Talhami, Ghada Hashem. "Women, Education, and Development in the Arab Gulf Countries.” Emirates Occasional Papers 53. United Arab Emirates: The Emirates Center for Strategic Studies and Research, 2004.

TANMIA. "Emiratisation in the Banking Sector: Factors Influencing Success and Failure." Centre for Labour Market Research and Information. Dubai: TANMIA, 2004.

—_. "Human Resource Report 2005.” Dubai: TANMIA, 2006.

Townsend, John. Oman: The Making of a Modern State. London: Croom-Helm, 1977.

UAE Government. “UAE Federal e-Government Portal” http://www.government.ae/ gov/ar/index.jsp.

Webb, Janette. “The Politics of Equal Opportunity." Gender, Work and Organization 4, no. 4 (1997): 159-169.

Willoughby, John. "Segmented Feminization and the Decline of Neopatriarchy in GCC Countries of the Persian Gulf." Comparative Studies of South Asia, Africa and the Middle East 28, no. 1 (2008): 184-199.

Winckler, Onn. Arab Political Demography: Population Growth and Natalist Policies. Brighton: Sussex Academic Press, 2005. 


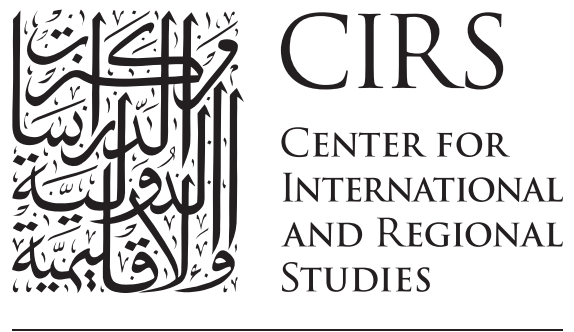

GEORGETOWN UNIVERSITY SCHOOL OF FOREIGN SERVICE IN QATAR

Center for International and Regional Studies Georgetown University School of Foreign Service in Qatar P.O. Box 23689

Doha, Qatar

http://cirs.georgetown.edu

$\mathrm{Tel}+97444578400$

Fax +974 44578401 


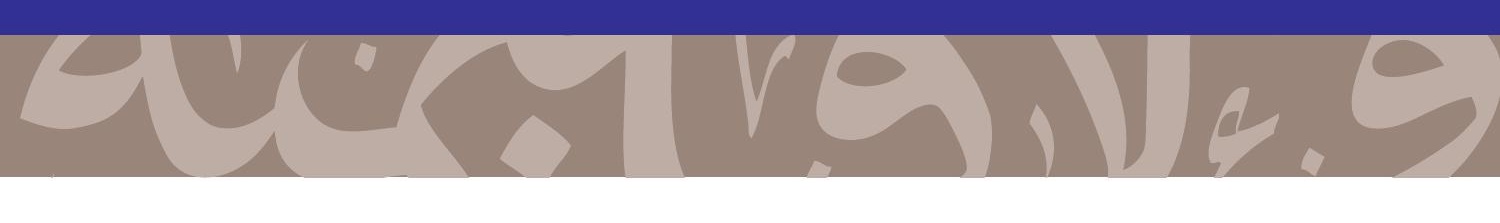

